\title{
An Indigenous Approach to Conflict, Migration, Negotiation and Mediation Across the People from Different Languages and Religions: The Cyprus Example
}

\author{
Senih Cavusoglu \\ Asst.Prof.Dr, Eastern Mediterranean University - North Cyprus
}

\section{THE STUDY PURPOSE:}

Cyprus is a small island in the eastern part of the Mediterranean sea. It has about the same size as the state of Connecticut with 660,000 inhabitants. The population of the island, according to the US State Department consists of: Greek-Cypriots 78\%, Turkish-Cypriots 18\%, Armenian, Maronite and Latin-Cypriots 4\%. They were dispersed all over the island, mosques and churches can still be found side by side and members of one community worked in the business of the other.

Both Greek and Turkish Cypriots have been living on the island of Cyprus for almost five centuries. Generally all their social habits, productions, consumptions, fears, happiness, enjoyment ways, and sadness have always been the same. Being different, their religions and languages couldn't obstruct this; they've shared the same faith. Although getting cross with each other in the past, the commonality of even the sorrow they felt is a proof that these communities possess a resolution culture, and not a conflict one!

In this study, the aim of resolution, instead of positive phenomenon will be reached via a negative phenomenon as a result of conflict. The aim will be tried to achieved by the help of messages inherited selected examples from the 150 works (suitcases) that took place in a happening, and my own work (suitcase) called 'Here are your pins grandmother'. The happening was titled Nomadifesta 2004(**) organized by Artrageous Group (***) (on the $22^{\text {nd }}$ of May 2004, at Kasteliotissa Space, Nicosia Cyprus) and invited artists and designers, local and international, were asked to use a suitcase not only as a simple means of transporting belongings, but as a platform for the expression of one's personal statement and as an arena of exchange and communication about migration.

Keywords: Migration-Cyprus-Cypriot-Conflict 


\section{METHODOLOGICAL APPROACH:}

Suitcases were used not only as a simple means of transporting belongings, but as a platform for the expression of one's personal statement and as an arena of exchange of communication. More than 150 suitcases, objects that are laden with historical exigencies with memories and meanings, are proposed as a shell of a big personal declaration with a mini exhibition. In this study, in the context of past and future, suitcases will be evaluated as a symbol of the search for a new beginning for the conflict resolution through the communities of the island. Besides being an only Turkish Cypriot artist actively attending to the Nomadifesta activity, as an approach, verbal interpretations of these visual mini exhibitions, or personal declarations in other words, is tried to be achieved.

\section{A Chronology Of Key Events Of The Cyprus Island}

1914 - Cyprus annexed by Britain, after more than 300 years of Ottoman rule.

1925 - Becomes crown colony.

1955 - Greek Cypriots begin guerrilla war against British rule. The guerrilla movement, the National Organisation of Cypriot Combatants (EOKA), wants enosis (unification) with Greece.

1956 - Archbishop Makarios, head of enosis campaign, deported to the Seychelles.

1960 - Cyprus gains independence after Greek and Turkish communities reach agreement on a constitution. Britain retains sovereignty over two military bases.

1963 - Makarios raises Turkish fears by proposing constitutional changes which would abrogate power-sharing arrangements. Inter-communal violence erupts. Turkish side withdraws from power-sharing. The termination of the Cypriot government's assaults on the Turkish Cypriots led to the creation of Turkish Cypriot enclaves, which corresponded to 3\% of the territory of Cyprus.

1963 December-26 December, Makarios was obliged to accept the Green Line.

1964 - United Nations peacekeeping force set up.

1968-The two communities agreed to come together in order to find a solution to the Cyprus problem.

1974 - Military junta in Greece backs coup against Makarios, who escapes. Within days Turkish troops land in north. Greek Cypriots flee their homes. 
1975 - Turkish Cypriots establish independent administration, with Rauf Denktash as president.

1977 - Makarios dies. Succeeded by Spyros Kyprianou.

1980 - UN-sponsored peace talks resume.

1983 - Denktash suspends talks and proclaims Turkish Republic of Northern Cyprus (TRNC). It is recognised only by Turkey.

1985 - No agreement at talks between Denktash and Kyprianou.

1988 - Georgios Vassiliou elected Greek Cypriot president.

1989 - Vassiliou-Denktash talks abandoned.

1992 - Talks resume and collapse again.

1993 - Glafcos Clerides replaces Vassiliou as president.

1997 - Failure of UN-mediated peace talks between Clerides and Denktash.

EU lists Cyprus as potential member.

2001 June - The UN Security Council renews its 36-year mission in Cyprus. Some 2,400 peacekeepers patrol the buffer zone between Greek and Turkish Cypriots.

2002 January - Clerides and Denktash begin UN-sponsored negotiations. Minds are concentrated by EU membership aspirations.

2002 November - UN Secretary General Kofi Annan presents a comprehensive peace plan for Cyprus which envisages a federation with two constituent parts, presided over by a rotating presidency.

2002 December - EU summit in Copenhagen invites Cyprus to join in 2004 provided the two communities agree to UN plan by early spring 2003. Without reunification, only the internationally recognised Greek Cypriot part of the island will gain membership.

2003 February - Tassos Papadopoulos defeats Clerides in presidential elections with just weeks to go before deadline for agreeing UN plan for the island's future.

2003 April - Turkish and Greek Cypriots cross island's dividing "green line" for first time after Turkish Cypriot authorities ease restrictions.

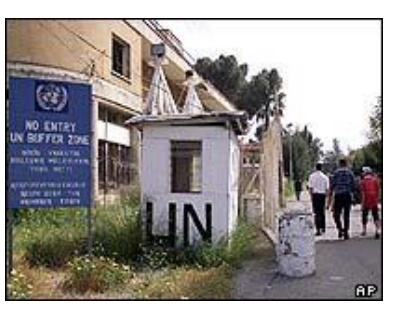

A green line has separated the two communities, since 1963 (Dean, p.56, 2000) 

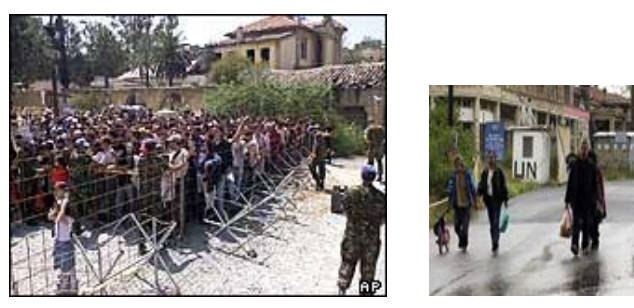

Cypriots from both communities crossed the 'green line', April 2003

Twin referendums on whether to accept UN reunification plan in last-minute bid to achieve united EU entry. Plan is endorsed by Turkish side but overwhelmingly rejected by Greek Cypriots.

20041 May - Cyprus is one of 10 new states to join the EU, but does so as a divided island.

\section{RECPUTILATION of Migration in Cyprus of 60's and 74:}

\section{Breakdown of the 1960 Constitution}

An incident between Greek Cypriots and Turkish-Cypriots on 21 December 1963 resulting in the deaths of a Turkish-Cypriot couple, led to the launching of 'a major attack on the Nicosian Turkish-Cypriots, the first stage in a campaign to settle the problem by force... The Greek-Cypriots aimed at the subjugation of the Nicosia Turks by a swift knockout blow, and, in consequence, the automatic surrender of the Turkish-Cypriot communities in the rest of the island. The Turkish-Cypriots were largely defenceless. (Crawshaw, pp.336-7,1978); (Oberling, p.87, 1982).

The incident refereed to above was followed immediately by a major Greek-Cypriot attack by the various para-military forces against the Turks in Nicosia and Larnaca (Kyle, p.10, 1994). During these early stages of violence that was to continue for the next decade, some GreekCypriot writers provide a different sort of version of these dire events which are never forgotten by the Turkish-Cypriots in Northern Cyprus (Polyviou, p.34,1980).

The number of Turkish-Cypriots who lost their homes became refugees in their own country by fleeing from their villages (103 villages) to safer areas (ghettos) between 1963 and 1974 were 25,000 (UN Security Council report 1964). 

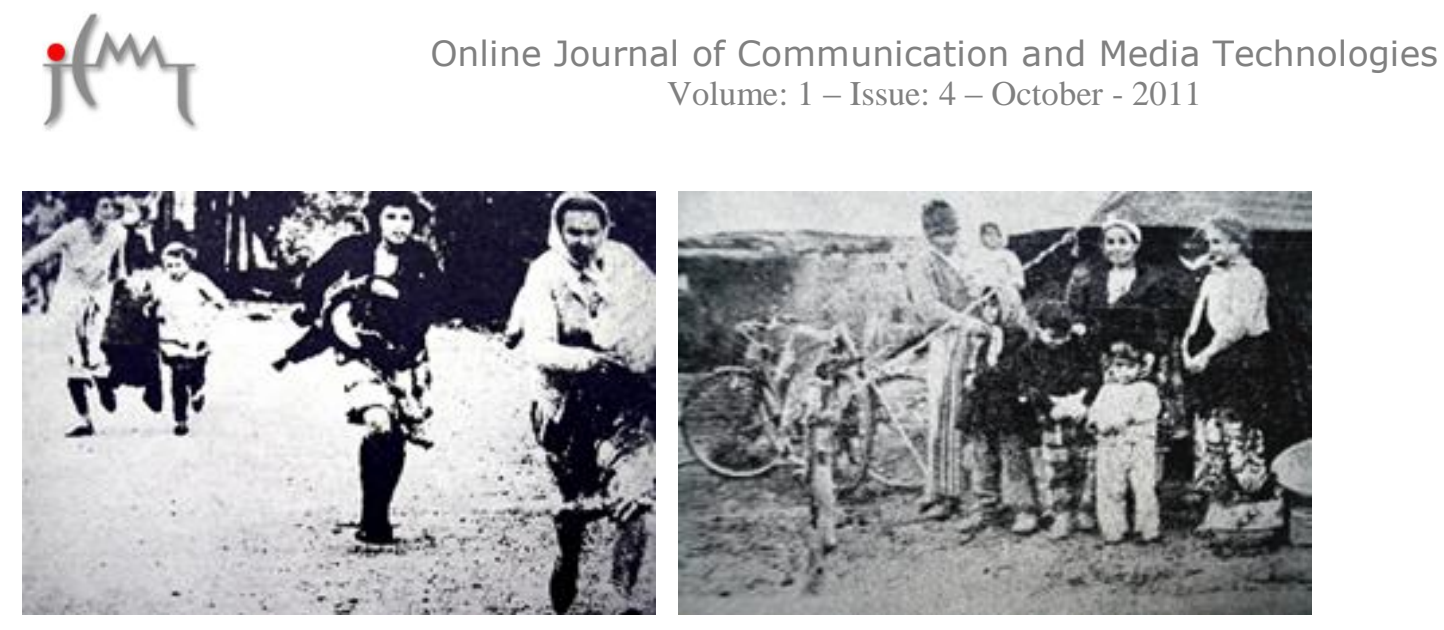

Migration and refugees of 1960's (Alasya, p.227, 1988).

\section{Communities Separate}

Between 1963-1974 Turkish-Cypriots were forced or, according to the Greek Cypriot claim, choose to migrate and form their homogenous enclaves. Due to this migration, the Turkish Cypriots left their lands, homes and migrated to live in small ghettos (Turkish cypriot enclaves which constituted 3\% of the island) (Sozen, p.13, 1998) shown in red on the map below (Oberling, p.145,1982).

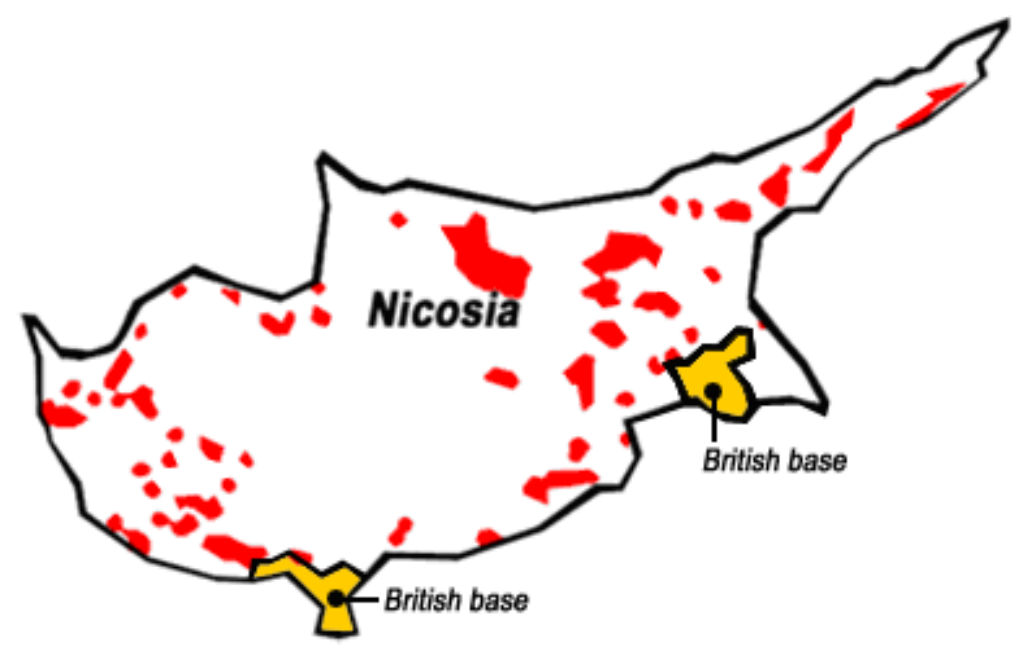

Map of Cyprus by the late 1960's

\section{Events and refugees in 1974}

When the military regime in Greece and the Greek Cypriot President (Makarios) were carried into a great conflict, and on July 15, 1974 the military regime in Greece sent troops to Island. As a result of this coup d'état (i.e., the invasion of the island by a Guarantor power-Greece), Turkey-under the provision of the Treaty of Guarantee of 1960-sent troops into the island on July 20, 1974 in order to prevent the union of the island with Greece, and to prevent the bloodshed. According to the Greek Cypriots, Turkey's action was an "invasion" and that she had been planning to actualize it for a long time. In that respect, the Greek coup d'état gave 
the pretext to Turkey to "invade" one third of the island (Sozen, p.17, 1998). Since then, the Turkish Cypriots and the Greek Cypriots have been living in completely separate zones divided by the Green Line (which was drawn in December 1963 at first for the capital city Nicosia). It has become an unwittingly an 'iron curtain' dividing the two communities, not only physically but also mentally (Harbottle, p.68, 1970) as North and South in Cyprus (North for Turkish Cypriots-South for Greek Cypriots) shown on the map below. On this basis the number of 'refugees' - those forced out, or those who abandoned homes because of fears of one side or another or under population exchange agreement (to North and to South) - would be 129,000 Greek Cypriots and 65,000 Turkish Cypriots.

The number of Greek Cypriots living in the north area in July 1974 was 129,000. (Source: Criton Tornaritis, the Attorney-General of the Greek Cypriot Administration, Legal Aspects of the Problem of Refugees in Cyprus 1975).

The number of Turkish-Cypriots subsequently displaced in population transfers was 65,000.

(Source: evidence to the UN by Turkish Cypriot documents 1975 re Vienna III).
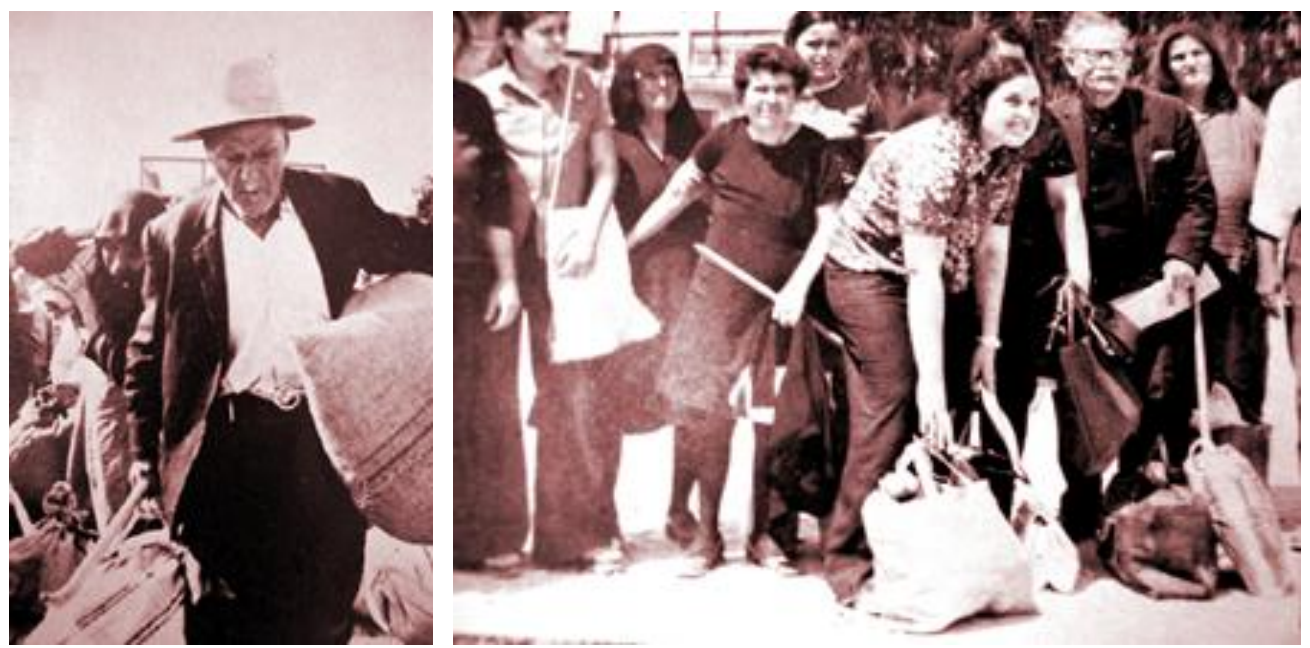

Migration and refugees of 1974's 


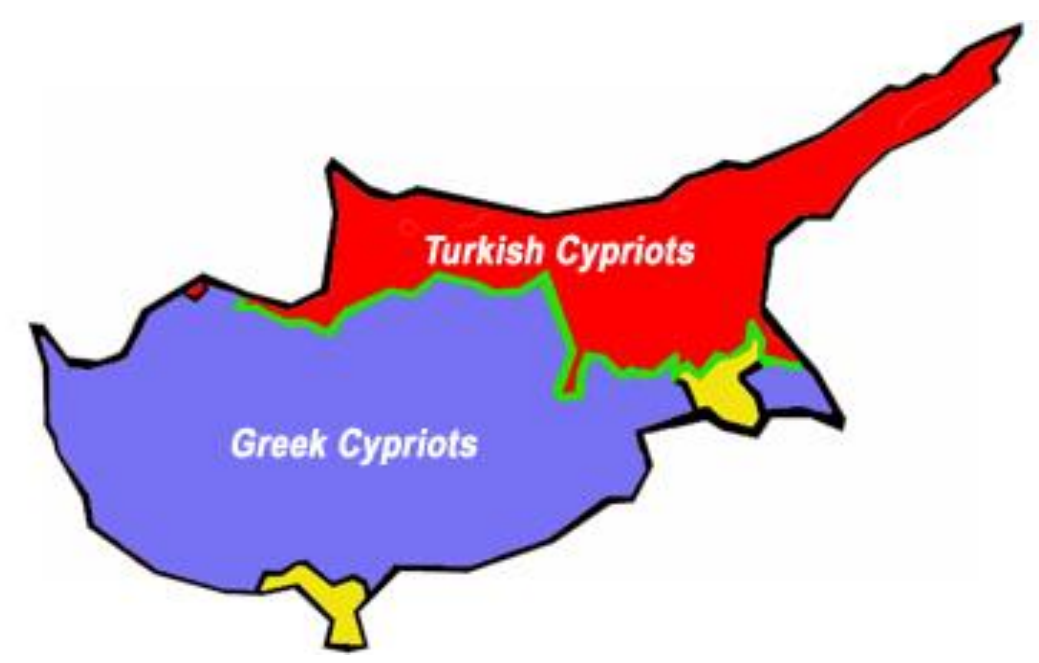

Map of Cyprus after 1974

\section{Issue and Theoretical Approach}

A suitcase and the expression 'Pack your suitcases', has another meaning for a Cypriot, besides that of holiday traveling. One hand, it draws memories from the 1960's and 1974 events which left most of the Turkish and Greek Cypriot population of the island refugees in their own land, with suitcases in their hands.

On the other hand, after 40 or 30 years of living divided, recent inter-communal negotiations and the United Nation's efforts for finding a solution to the political problem, have created the impression that; these people for both communities might have to pack their suitcases once more. A suitcase implies a movement of population, creates a feeling of transience and expectation, raising a big question mark as to what is happening now, who lives where or where will one's house be in the future. The agony of loss, depression of a postwar trauma, and the fear of history repeating itself are embedded in one's mind as a picture of a packed suitcase ready to go. 

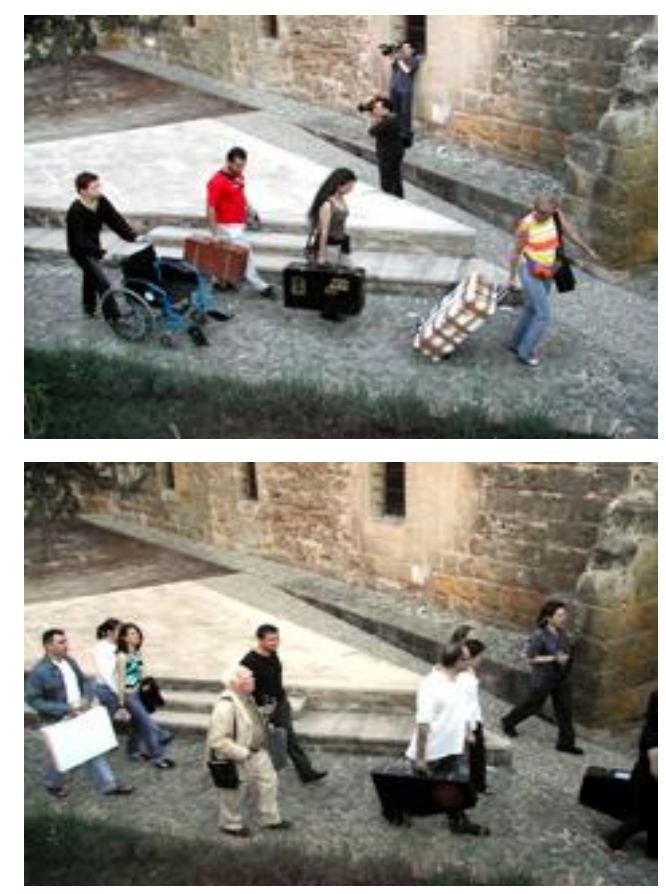

\section{Artistic Approaches to the Changed Meaning of Suitcase}

Today, reaching all the possibilities of the world and technological life as a result of visual communication era is a matter of seconds. In this quick and continous information medium, our brain is filled up with necessary/unnecessary, far but close whats ups. Therefore, we end up with brain eclipses as a result of this information storm... Either we start to be more careing or careless at all. In the artistic activities dimension, through installations and group works, a reflection posture againts what happens in the world (in the past or future) becomes possible with a political standing and having conceptual works.

In artistic means, reactions againts actions have started to include an answer exactly with the same speed with these speedy and spontaneous developments. As a result, the art that is presented in a day or two and consumed within the same time, is in front of us today as a reason/end product relation.

Suitcases used here are not just a reference or a metaphor to a nostalgic past, but they are used in order to represent an active split entity. The suitcase signifies the moment or rapture, the instance in which the subject is torn out the web of correctedness that contained him or her through an invisible net of belonging. The reference of suitcase to some part of history or some part of the self left behind indicates memory of something that has been lost or found. 
Here, what you will find is the reactionist standing against what was lived in the past of the people, or their children, whose houses, villages, and pasts have been taken from them.

\section{Verbal Interpretations of Visual Personal Statements}

On May $22^{\text {nd }} 2003$, around 500 people, artists and visitors gathered at Solomou Square in Nicosia. Cypriot and foreign artists of different age groups, performers, actors, musicians, marched to Kasteliotissa space with a suitcase in their hands. Lastly 150 suitcases were arranged on the floor or hanged on the walls of the Medieval Hall.

Some of them glowed with interior light, some made strange noises, some rolled on wheels by themselves, some invited the audience to sit inside them. Others were locked and other became stages for a physical performance or a shadow play. The gallery gave the impression of being a train station in peek hour, of being in a state of transience mixed with the ambience of a celebration. It seemed to be a circus of suitcases of the bizarre, a bazaar of ideas. In some cases a suitcase became a platform of a personal autobiographical statement, in others a humoristic expression of recent events like a terrorist suitcase beeping like a bomb. A suitcase became a symbol of local historical events and a container of memories. Taken as a whole, 150 different ideas fused together for 24 hours.

150 closed cases, 'suitcases', as if their interiors are empty, as if standing there meaningless, or as if occupying nothingness, with many things or thingless.

Hundreds of people, with their suitcases, as if waiting for the time to move, reluctantly or impatiently in the Solomou Square ....
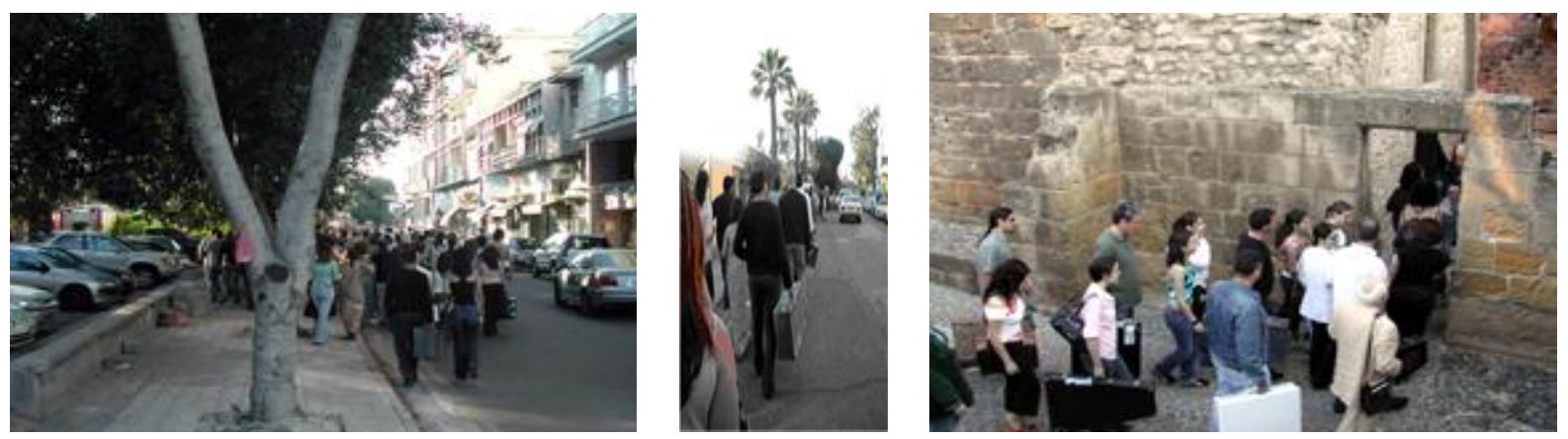
And the time to move... A silent mass-walking... A sadness...Only minutes to walk away from fear or past...

200 meters long road to Paphos Gate, as if a road of 3 days... The suitcases, and their beholders are getting in, one by one... The suitcases are laid down and opened. Suddenly, each and every suitcase brings dramatic, comic, incitement, irritant, unbearable, indistinct, unstable panic, shocking messages and then we're started to tour (who knows where)...

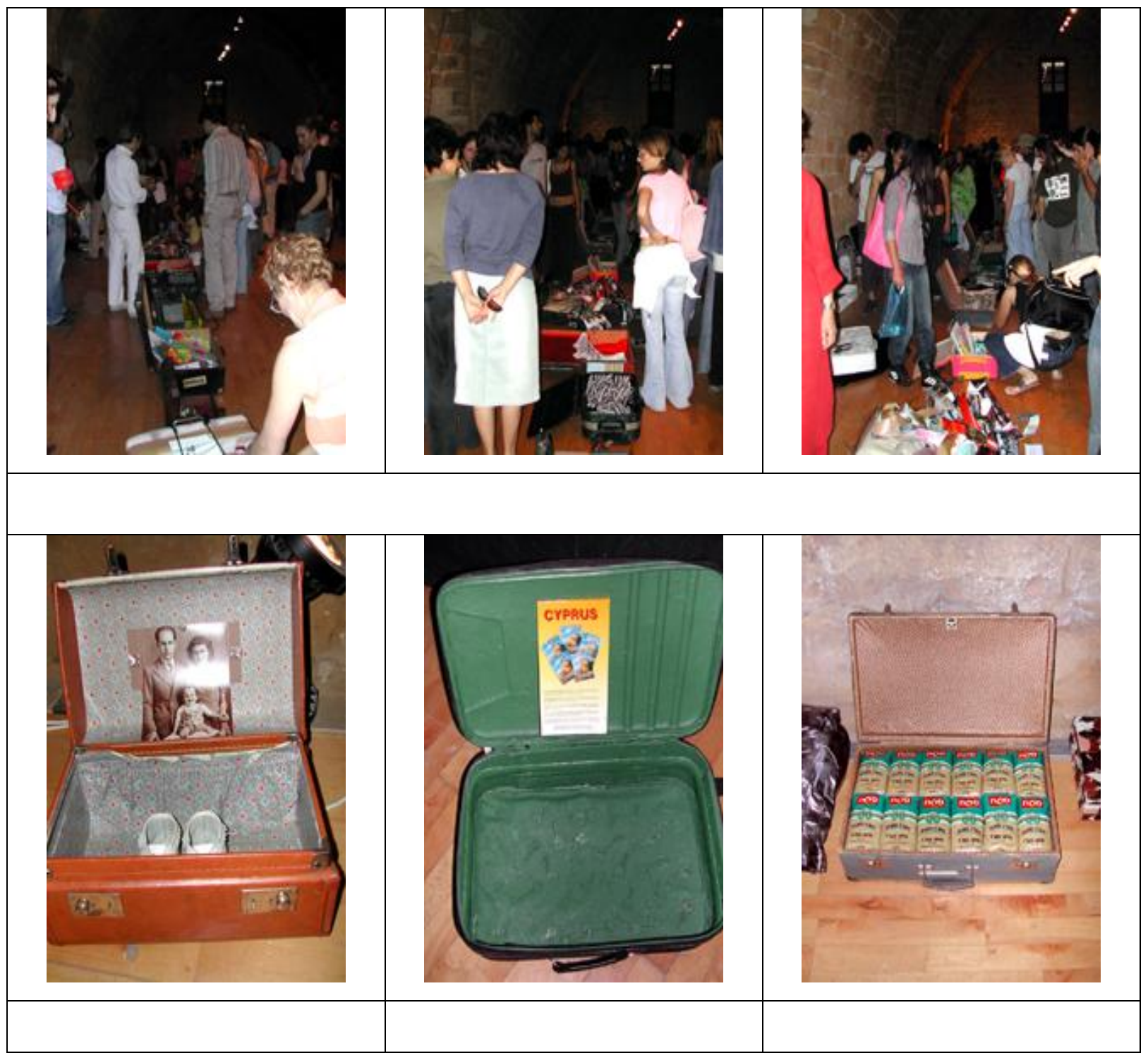


$j\left(m m^{\prime}\right.$

Online Journal of Communication and Media Technologies

Volume: 1 - Issue: 4 - October - 2011

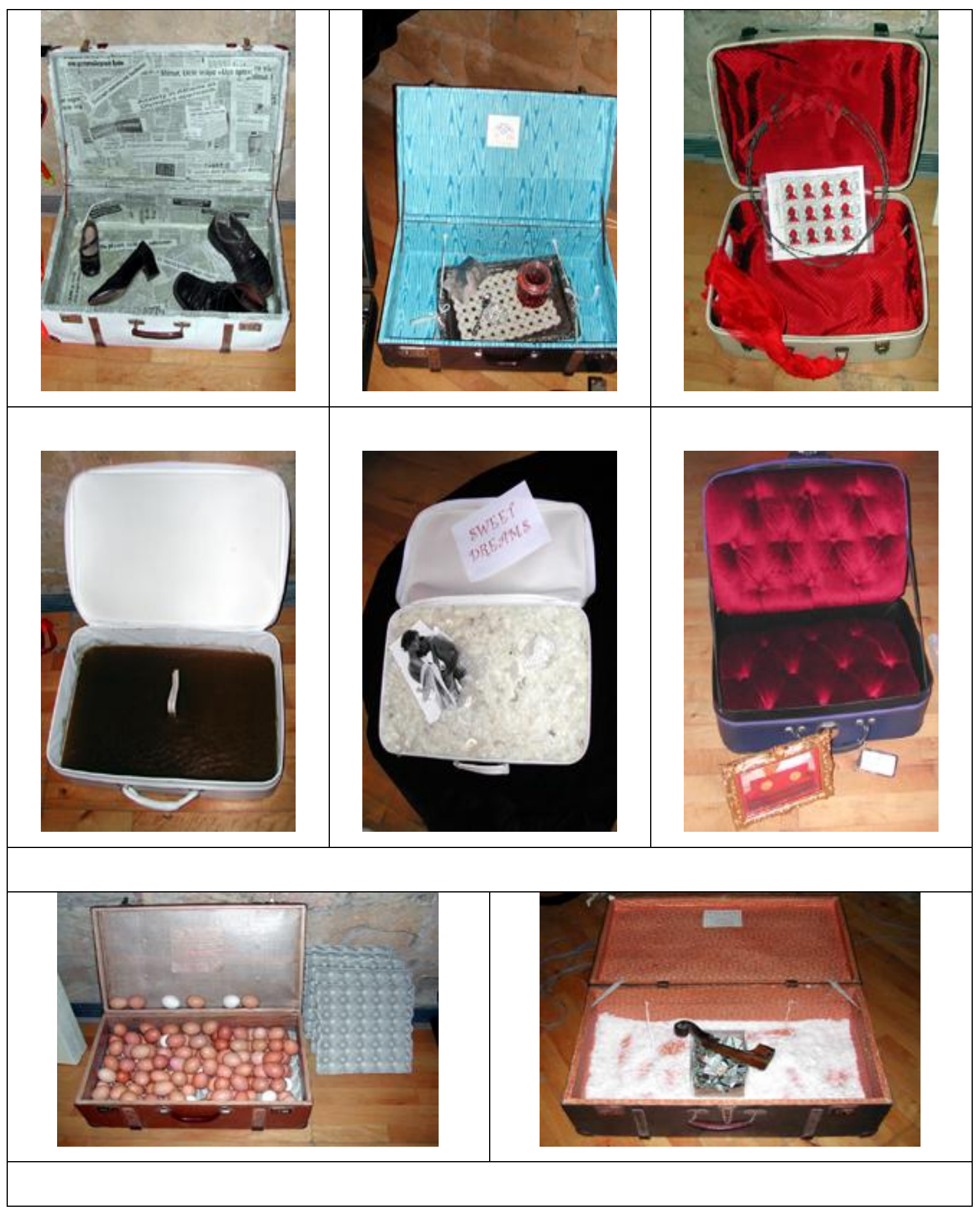

(C) Online Journal of Communication and Media Technologies 


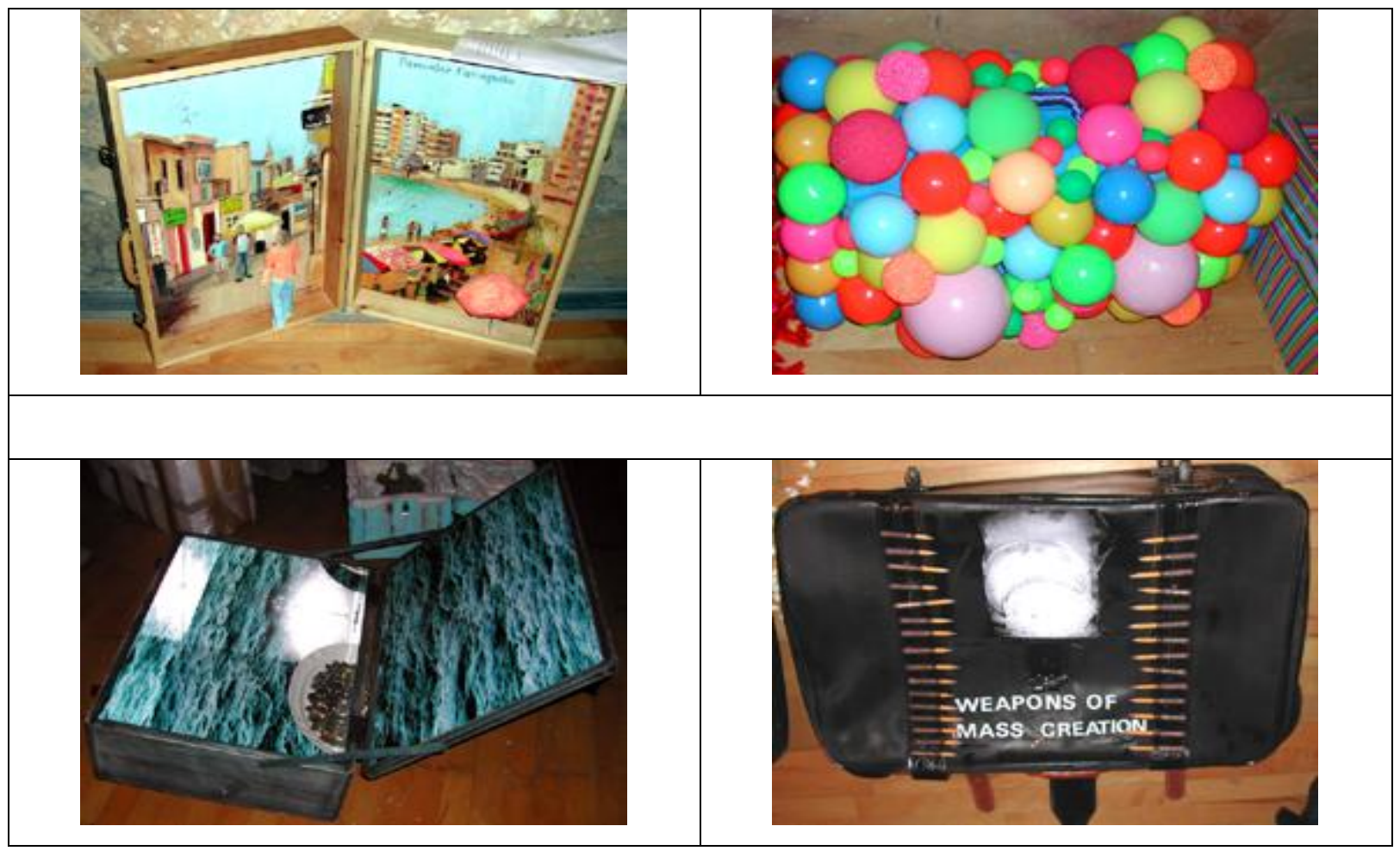

\section{MAJOR RESULTS AND CONCLUSION}

\section{"Here are your pins grandmother"}

As a cypriot saying "We had to move, without taking even a pin". We heard this a lot from the immigrated mothers, fathers, and grandmothers. At this moment, does an immigrant only leave only a home, belongings, a garden and a ride to the unknown or to a new life?

Thousands of pins (as a single visual image) within the suitcase were installed to get closer to the truth and embrace it as a result... and the suitcase takes in them like a photograph camera simultaneously as a single image. The pins are the main visual character, which are both captivating and defining, narrating both leave and return. That is the objective of the camera(suitcase) has been opened, and in that short time until it was closed, the pins could gathered together within as much as possible.

This conceptual moment is a political antagonism or a communal criticisim or a call to dreaming, memories, past, ending, or getting rid of sorrow. 
In this artistic work called 'here are your pins grandmother', this truth that bears both sorrow and compassion at the same time, has been worked out with some humor and same sorrow, narrated through the philosophy that each leaving is a return. It thus, focuses attention to such a heaving lost acting as if taken lightly.

Nomadifesta has been the most emotional, bicommunal or intercommunal artistic activities of Cyprus history for the last 40 years. It was a trial to guide (light) the way towards the real world today, that is mediation or future against carefully set up ordinary worlds, spoiling orders, classical dreams, unrealities or left-behinds, obsessions.

The outcome of Nomadifesta was very encouraging and positive. The event brought together artists and audience in a situation where the "precious" and "untouchable" art object was replaced by a platform of exchange and communication. The artists in a kind of performative walk to set up the show on the spot transported the art objects. A non-curated and a nonsponsored event, instead a spontaneous act of the artists' good faith and the Artrageous Group initiative.

"Here are your pins grandmother" installation work visuals.
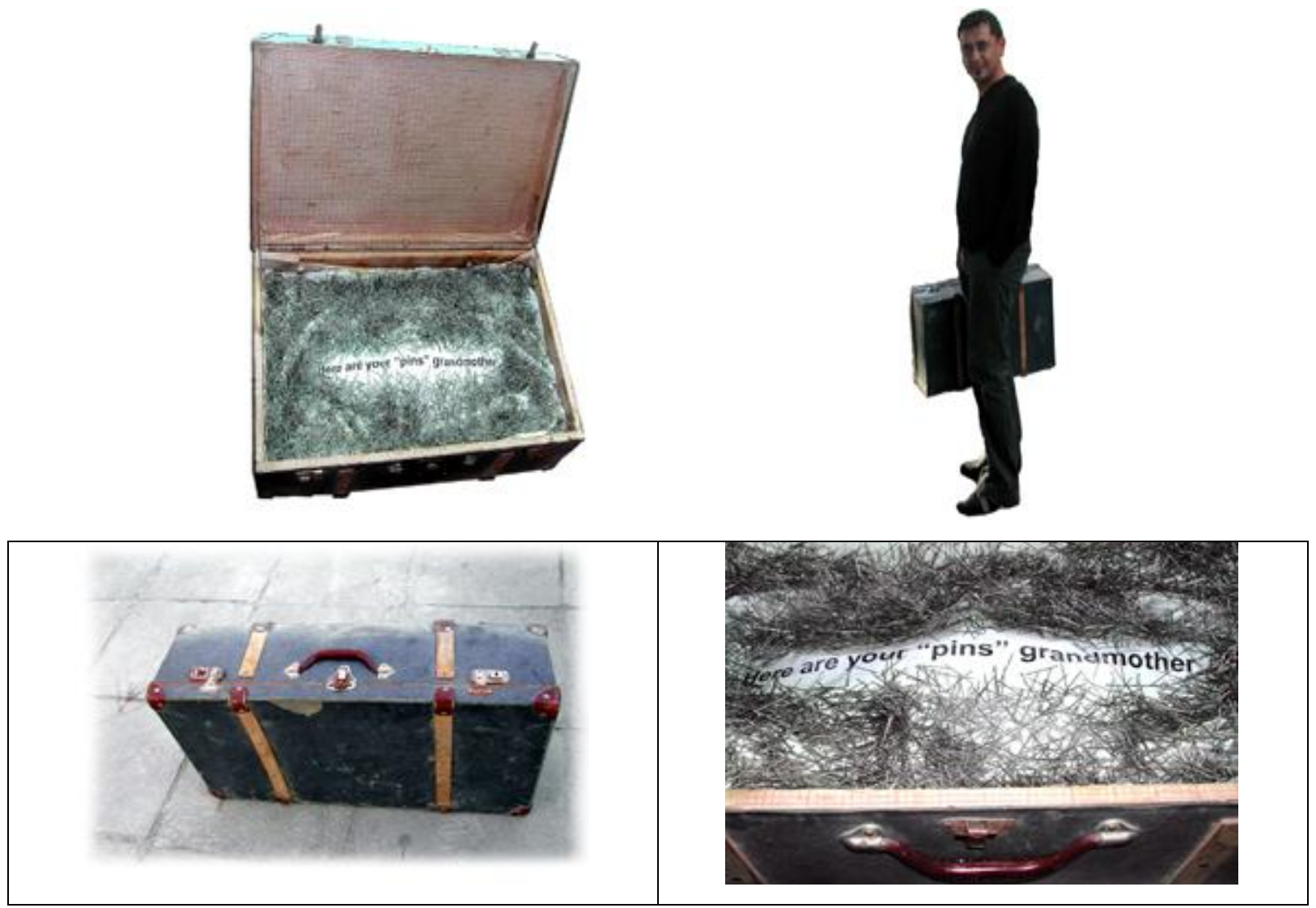


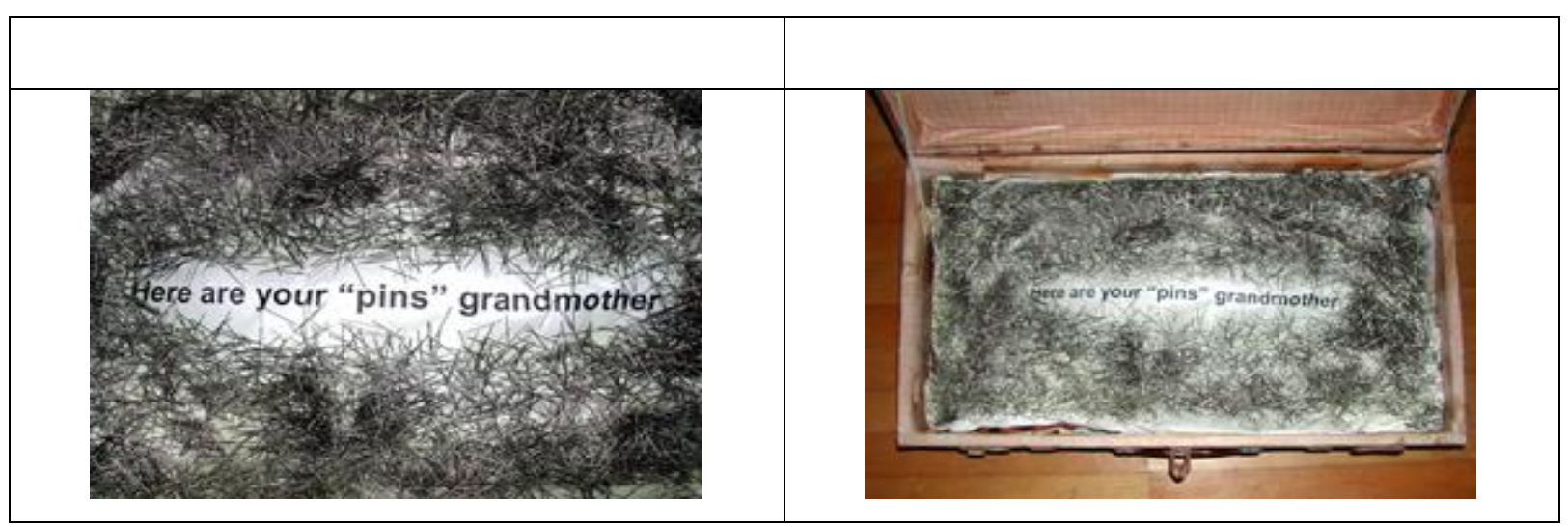

\section{(*)Biosketch:}

Asst.Prof.Dr. Senih ÇAVUŞOĞLU, senih.cavusoglu@emu.edu.tr

Born in Paphos,Cyprus 1969. He graduated in 1990 from Gazi University/Ankara, Faculty of Education, Dept. of Art and Craft, with a BA. He completed his MA degree in 1992 and his Ph.D. degree in 1996 at Hacettepe University/Ankara, Faculty of Fine Arts, Dept. of Graphic Design. He worked as an instructor in Eastern Mediterranean University, Faculty of Architecture, Dept. of Interior Architecture 1998-2007. He is currently working as the Chair of the Department of Visual Arts and Visual Communication Design at Eastern Mediterranean University, Faculty of Communication and Media Studies. Senih Cavusoglu have several national and international awards and mentions for his graphic design works, short films and for his photography art. He has several professional designs, academic and bi-communal activities. In 2007 he won the $1^{\text {st }}$ prize in WOUD2008 (World Olympiad for Urban Design) International Logo Competition held in Iran by International Art \& Architecture Research Association (IAARA) under UN-HABITAT. His poster in the STDs brief had been awarded as one of the best of 2008 year's Good 50x70 contest.

\section{(**)Nomadifesta 2004:}

Nomadifesta 2004 organized by Artrageous Group on the $22^{\text {nd }}$ of May 2004, at Kasteliotissa Space, Nicosia Cyprus and invited artists and designers, local and international, to use a suitcase not only as a simple means of transporting belongings, but as a platform for the expression of one's personal statement and as an arena of exchange and communication about migration.

150 works collected from Cypriot artists including the foreign artists came from 17 different countries. Some artists from Australia, China, Korea, India, Germany, Spain, Greece, USA, UK and Portugal send their suitcases from abroad. Artists from Malta, Italy and Israel traveled to Cyprus for the event. Other participating countries included Iran, Jordan, Syria, and Sweden.

\section{(***)Artrageous Group:}

The Artrageous Group was formed by three Cypriot artists to create a social-political manifestation that focuses on the role of the artist as an agent for public awareness who experiments however within a contemporary art context. Created in march 2004, Artrageous was launched on the initiative of the artists, Klitsaantoniou, Panayotis Michael and Melita Couta. 


\section{$\underline{\text { References }}$}

Adams, Thomas W. and Cottrell, Alvin J., Cyprus Between East and West, the Johns Hopkins Press, Baltimore, 1968.

Alasya, Halil Fikret, Tarihte Kibrıs (Cyprus in History), Ankara 1988.

Bercovitch, Jacob, ed., Resolving International Conflicts. Boulder: Lynne Reinner, 1996.

Birand, Mehmet Ali, Thirty Hot Days, Oxford, 1985.

Bitsios, Dimitri S., Cyprus: The Vulnerable Republic, Institute for Balkan Studies, Thessaloniki, 1975.

Camp, Glen D., Greek-Turkish Conflict Over Cyprus, Political Science Quarterly, 95:43-60, 1980.

Clerides, Glafkos, Cyprus: My Deposition, Vol 1. Nicosia: Alithia Publishing Co. Ltd, 1989.

Clerides, Glafkos, Cyprus: My Deposition, Vol 2. Nicosia: Alithia Publishing Co. Ltd, 1989.

Clerides, Glafkos, Cyprus: My Deposition, Vol 4. Nicosia: Alithia Publishing Co. Ltd, 1990.

Clerides, Glafkos, Cyprus: My Deposition, Vol 4. Nicosia: Alithia Publishing Co. Ltd, 1992.

Cohen, Raymond, Negotiating Across Cultures, $2^{\text {nd }}$ printing, Washington D.C.: US Institute of Peace Press, 1992.

Constantinides, Alecos, A Revision of History, Alithia, Nicosia, 14 November 1979.

Coufoudakis, Van (ed.), Essays On The Cyprus Conflict, New York, 1976.

Couloumbris, Theodore A. and Hicks, Salli M. (eds.), U.S. Foreign Policy Towards Greece and Cyprus: The Clash of Principle and Pragmatism, Centre for Mediterranean Studies, Washington, 1975.

Crawshaw, Nancy, The Cyprus Revolt, London, 1978.

Dean, Corinna, Drawing a line, Blue Print: Architecture, Design and Contemporary Culture Magazine, England, July 2000.

Denktash, Rauf R., The Cyprus Problem, Nicosia, 1974.

Denktash, Rauf R., The Cyprus Problem and Remedy, Nicosia: Turkish republic of Northern Cyprus Press Office, 1992.

Durrell, Lawrence, Bitter Lemons, London: Faber and Faber Ltd, 1973.

Ehrlich, Thomas, Cyprus, 1958-1967: International Crises and the Role of Law, New York and London: Oxford University Press, 1974.

Faulds, Andrew (ed.), Excerpta Cypria for Today, London 1998. 
Foley, Charles, (ed.), The Memories of General Grivas, New York: Frederich A. Praeger, Inc., 1965.

Gazioğlu C. Ahmet, Cyprus: The Island of Sustained Crises, Vol.2, March 1964-August 1964, Nicosia, 2002

Gibbons, H, S., The Genocide Files Charles Bravos, London, 1997.

Grivas, George, General Grivas on Guerilla Warfare, New York and Washington: Frederich A. Praeger, Inc., 1965.

Harbottle, Michael, The Impartial Soldier, London, New York and Toronto: Oxford University Press, 1970.

Heinze, Christian, The Cyprus Conflict: The Western Peace System is Put to the Test, $2^{\text {nd }}$ edition, Nicosia, 1977.

Kedourie, Elie, The Cyprus Problem and its Solution, London, 1973.

Kyle, Keith, The British and Cyprus in 1963, Report no.37, Friends of Cyprus, London, 1994.

Oberling, Pierre, The Road to Bellapais: The Turkish Cypriot Exodus to Northern Cyprus, New York: Columbia University Press, 1982.

Patrick, Richard A., Political Geography and The Cyprus Conflict, 1963-1971, Waterloo, Ontario, 1976.

Polyviou, Polyvios G., Cyprus: The Tragedy and the Challenge, Washington, D.C.: American Hellenic Institute, 1972.

Report of the Secretary-General to the Security Council on the United Nations operation in Cyprus, Document S/5950, 10 September 1964.

Report of the Secretary-General to the Security Council on the United Nations operation in Cyprus, Document S/5764, 15 June 1964.

Salem, Norma (ed.), Cyprus: A Regional Conflict and Its Resolution, London, 1992.

Sonyel, Salahi R., Cyprus: The Destruction of a Republic (British documents 1960-1965), Cambridgeshire, England, 1997.

Sozen, Ahmet: The Cyprus Conflict and the Negotiations: A Political and International Law Perspective, Ankara, 1998.

Stavrinides, Zenon, The Cyprus Conflict: National Identity and Statehood, Nicosia, 1975.

Volkan, Vamik D., Cyprus-War and Adaptation, Charlottesville, Va., 1979. 